Latin American Monographs, No. 24 Institute of Latin American Studies The University of Texas at Austin 
THIS PAGE INTENTIONALLY LEFT BLANK 


\title{
CRISIS
}

\section{in Costa Rica}

\section{The 1948 Revolution}

\author{
by JOHN PATRICK BELL
}

PUBLISHED FOR THE INSTITUTE OF LATIN AMERICAN STUDIES

BY THE UNIVERSITY OF TEXAS PRESS, AUSTIN AND LONDON 
Copyright (C) I97 I by John Patrick Bell First paperback printing 2014

All rights reserved

Printed in the United States of America

Requests for permission to reproduce material from this work should be sent to:

Permissions

University of Texas Press

P.O. Box 7819

Austin, TX 78713-78I9

http://utpress.utexas.edu/index.php/rp-form

Library of Congress Catalog Number 77-I65920

ISBN 978-0-292-77258-8, paperback

ISBN 978-0-292-77259-5, library e-book

ISBN 978-0-292-77260-I, individual e-book 
TO

Dora Inés Silvetti Bell

For her versatile and constant assistance

The author dedicates this book

With love and gratitude 
THIS PAGE INTENTIONALLY LEFT BLANK 